\title{
Interaction of Genotype $x$ Sowing Date on Yield and Associated Traits of Soybean [Glycine max (L.) Merrill] over Two Cropping Seasons in a Humid Agro-ecological Zone of South-Eastern Nigeria
}

\author{
G. E. Nwofia ${ }^{1}$, R. E. Edugbo ${ }^{1}$ and E. U. Mbah $^{1}$ \\ Received : $27^{\text {th }}$ October $2015 /$ Accepted : $17^{\text {th }}$ March 2016
}

\begin{abstract}
The study evaluated four soybean genotypes in 2012 and 2013 cropping seasons in the humid tropics for growth, seed yield and other reproductive characters. A split plot in randomised complete block design with four replications was used at National Cereals Research Institute,

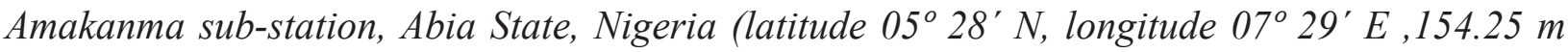
asl). Sowing date was the main plot treatment while soybean genotypes were fitted into the subplots. Sowing date significantly affected soybean yield and yield components with the month of July pointing out as most appropriate sowing time for the crop in the humid tropics of southeast Nigeria. TGx1485-1D soybean genotype consistently exhibited high performance in seed yield and in most of the characters studied across both environments while TGx1987-10F had the least, hence can be tipped as good breeding material for development of high yielding soybean varieties that would have high adaptation to the agro-ecology. Correlation and path analysis revealed that number of pods plant-1 among other traits was the most important contributor to seed yield and demands close attention as selection index for crop improvement. TGx1485-1D though high yielding exhibited low yield stability across both environments in the GGE bi-plot ranking where it ranked closest to the ideal genotype, hence, can be recommended as suitable for cultivation in the humid tropics of southeast Nigeria. Also, the genotype could be exploited for future breeding programs aimed at boosting research in developing high yielding, adaptable, disease resistance and stable genotypes for the region.
\end{abstract}

Keywords: Soybean, genotype, environment, seed yield, stability, adaptability, GGE bi-plot

\section{INTRODUCTION}

Soybean (Glycine max L. Merrill), which is one of the most important legume crops in the world is gaining increased cultivation attention in the humid tropics (Akande et al., 2007) because of its high quality protein, 85 per cent cholesterol free oil content (Malik et al., 2007) and nutritional value for humans and livestock as well as its ability to maintain soil fertility (Ngalamu et al., 2013). According to Rao et al. (2002), the crop is consumed in the form of soybean milk, soybean cheese, soybean curd, tofu and soybean sprouts, among others. It plays a significant role in boosting the immune system and general health of the human body
(Murray-Kolb et al., 2003) as well as serves as dietary supplement for diabetics (Azadbkht et al., 2003).

Currently, soybean has gained increased attention in Nigerian agriculture, because it is a veritable source of high quality protein and vegetable oil (Akande et al., 2007). Successful growing of the crop is characterized by low agricultural input, though, according to Aduloju et al., (2009), its grain yield is relatively low; below $1,000 \mathrm{~kg} \mathrm{ha}^{-1}$ compared to grain yield from countries such as USA with more than $2,500 \mathrm{~kg} \mathrm{ha}^{-1}$. 
Sowing date is one of the major factors that influence growth and yield of legumes and positively correlates phenological phase of the plant with the environmental factors that influence its performance (Azari and Khajepour, 2003). The effects of sowing date on seed yield vary with genotypes of soybean hence the need to study genotype $\mathrm{x}$ environment interaction becomes imperative to be able to identify genotypes which are stable when subjected to growth under different environments.

For effective selection for high seed yield in soybean, a good knowledge of yield contributing characters and the interrelationships among themselves and with yield is important and this can be achieved through correlation and path analysis studies. Correlation coefficient (r), measures the degree of association between characters while path analysis indicates an effective means of partitioning the correlation coefficients into direct and indirect effects of the component characters on seed yield under which crop improvement programmes can be executed and achieved.

Stability analysis, which helps to identify and select the most stable, high performing crop genotypes that are best suitable under a given set of environmental conditions play a cardinal role in crop improvement techniques. According to Nwofia (2012), evaluating cultivars in contrasting environments and across years with the essence of determining their desirability, adaptability and stability is an essential instrument in ensuring appropriate food security. Therefore, the objectives of the study were to evaluate growth, yield and yield component responses of some soybean genotypes to sowing date and cropping seasons in lowland humid tropical environment.

\section{MATERIALS AND METHODS}

Field experiments were carried out in 2012 and 2013 cropping seasons at the research farm of the National Cereals Research Institute (NCRI),
Amakama, Abia State, Nigeria. The area falls within latitude $05^{\circ} 28^{\prime} \mathrm{N}$ and longitude $07^{\circ}$ $29^{\prime} \mathrm{E}$ with an altitude of $154.25 \mathrm{~m}$ above sea level in the humid southeast agro-ecological zone of Nigeria. The experimental location is characterised by a bi-modal pattern of rainfall typical of southern part of West Africa, which has the dry season harmattan (November April) and the wet season (May - October). The total annual rainfall of the location was 2,200.9 $\mathrm{mm}$ (2012) and 2,023.2 mm (2013).

The two experimental fields, which had been under fallow for two cropping seasons with vegetation cover such as Imperata cylindrica, Panicum maximum, Ageratum conyzoides, Pueraria phaseoloides and Chromolaena odorata prior to the establishment of the experiment were clear-ploughed, harrowed twice and levelled with a tractor mounted equipment. Plant debris left unburied in the site, were removed manually from the field before the experimental plots were marked out. Each unit plot size was $3 \mathrm{~m} \times 3 \mathrm{~m}$ with $1 \mathrm{~m}$ spacing between each plot. Pre-sowing soil sample analysis was done to determine the physicochemical properties of the farm land. $\mathrm{T} h \mathrm{~h}$ soil type is sandy loam, which belongs to the order ultisol and classified as Paleulstult. The chemical properties of the soil profile $(0-15$ $\mathrm{cm})$ obtained from the two experimental sites were 1.32 and $1.31 \%$ organic matter, 0.97 and $0.85 \%$ organic carbon, 0.056 and $0.035 \%$ total nitrogen $(\mathrm{N}), 10.50$ and $14.30 \mathrm{mg} / \mathrm{kg}$ available phosphorus $\left(\mathrm{P}_{2} \mathrm{O}_{5}\right), 0.08$ and $0.077 \mathrm{cmol} / \mathrm{kg}$ exchangeable potassium $\left(\mathrm{K}_{2} \mathrm{O}\right), 2.50$ and 2.56 $\mathrm{cmol} / \mathrm{kg}$ total exchangeable acidity (TEA), 6.321 and $6.507 \mathrm{cmol} / \mathrm{kg}$ cation exchange capacity (CEC), and 5.06 and $4.89 \mathrm{pH}$ (1:2.5, Soil:Water) in 2012 and 2013 cropping seasons, respectively.

The treatments comprised of one medium maturing (TGx 1448-2E) and three early maturing (TGx 1485-1D, TGx 1987-1F and TGx 1835-10E) soybean genotypes, which were sown across six sowing dates corresponding 
to early June, late June, early July, late July, early August, late August in 2012 and 2013, cropping seasons. The treatments were fitted into a split plot in randomised complete block design (RCBD) with four replications. Sowing date served as the main plot while soybean genotypes were fitted into the sub-plots.

Soybean seeds were sown on flats at defined spacing of $50 \mathrm{~cm}$ between rows and $20 \mathrm{~cm}$ within rows giving a population density of 100,000 plants per hectare. Weed control measures were carried out using both postemergence (Round UP ${ }^{\mathrm{TM}}$ and Paraquat ${ }^{\mathrm{TM}}$ ) and pre-emergence (Pendillin ${ }^{\mathrm{TM}}$ ) herbicides at the rate of $160 \mathrm{ml} / 20 \mathrm{~L}$ of water in knap sack sprayer and then manual weeding was done at 8 and 12 weeks after sowing (WAS). Insect infestation was controlled using Cypermethrin $10 \mathrm{EC}$ at the rate of $180 \mathrm{ml} \mathrm{15-1} \mathrm{L} \mathrm{of} \mathrm{water} \mathrm{in} \mathrm{knap} \mathrm{sack}$ sprayer at 3 and 6 weeks after sowing (WAS). Fertilizer application (NPK 15:15:15) at the rate of $300 \mathrm{~kg} \mathrm{ha}^{-1}$ was carried out at 4 WAS.

Growth, phenological and yield characters of soybean were obtained at 6 WAS. Data were collected on plant height $(\mathrm{cm})$, number of branches plant ${ }^{-1}$, number of leaves plant ${ }^{-1}$, number of nodules plant $^{-1}$, nodule dry weight plant $^{-1}$, root length plant ${ }^{-1}(\mathrm{~cm})$, number of days to flowering, number of days to physiological maturity, and pod filling time while yield characters such as number of pods plant ${ }^{-1}$, number of seeds plant ${ }^{-1}, 100$-seed weight plot $^{-1}$ and grain yield $\left(\mathrm{kg} \mathrm{ha}^{-1}\right)$ were also obtained. The total number and dry weight of nodules plant ${ }^{-1}$ were obtained from four plants located in the inner rows of each plot. Plants were carefully uprooted, the roots thoroughly washed in a bucket filled with water and then rinsed with distilled water. The length of the roots were measured with a meter rule, number of nodules counted and recorded while the weight of the oven-dried nodules was obtained with the aid of a sensitive weighing balance (Mettler Toledo). Phenological characters such as number of days to flowering, physiological maturity and pod filling period were recorded as the number of days from sowing to the day of first flowering, number of days from sowing to when at least a single pod on the plant indicated its mature brown colour (R7), and number of days from seed filling (R5) to when one pod at the top 4-5 main stem nodes has at least one seed that is physiologically mature (R7) according to Fehr and Caviness (1977), respectively. Yield parameters such as number of pods plant $^{-1}$, number of seeds plant ${ }^{-1}, 100$-seed weight plot $^{-1}$ and seed yield $\left(\mathrm{kg} \mathrm{ha}^{-1}\right)$ were recorded.

The stability of the four soybean genotypes was estimated using genotype main effect and genotype by environment (GGE) bi-plot models, which permits comparison among genotypes with a reference genotype. The method specifies position of an ideal genotype with the highest mean value compared to all the other genotypes and be absolutely stable, which implies that it expresses minimal genotype $\mathrm{x}$ environment interaction.

The data were subjected to analysis of variance while mean separation was performed with T-tests (LSD) using GLM procedure of SAS system (1997). Multiple correlation analysis was carried out to examine the interrelationships among the traits using SPSS for Windows, Version 17.0 (SPSS, 2010), while direct and indirect effects of each character to seed yield were determined by path coefficient technique as outlined by Dewey and Lu (1959) with the formula: $r i j=p i j+\Sigma$ rik . pkj, where; rij $=$ cordial relationship between the independent character (i) and the dependent character (j) as detected by the correlation coefficients of the soybean genotypes; pij = direct effects of the independent character (i) on the dependent variable (j) as detected by the correlation coefficients of the soybean genotypes; rik . pkj = summation of components of indirect effects of the independent character (i) on the dependent character (j) via all the independent characters (k). The residual effects were estimated using the formula: $\sqrt{ } 1-\mathrm{R} 2$, where, $\mathrm{R} 2=\Sigma$ pij . rij. 
The stability of the soybean genotypes across the two years were evaluated using Genotype and Genotype $\mathrm{x}$ Environment interaction (GGE) biplot model according to Yan et al., (2000) and Gabriel (1971). A set of concentric circles were created using the ideal genotype at the concentric centre as a reference to rank the other genotypes while a performance line passing through the origin of the bi-plot was used to determine mean performance of each of the other genotypes.

\section{RESULTS AND DISCUSSION}

Significant genotypic influence $(\mathrm{P} \leq 0.001)$ was achieved in number of leaves plant ${ }^{-1}$ by years, sowing dates, year $\mathrm{x}$ sowing date interaction while year $x$ genotype interaction was significant at $\mathrm{P} \leq 0.01$. Soybean genotype and year $\mathrm{x}$ sowing date $\mathrm{x}$ genotype interactions did not show any significant variations between the treatment means (Table 01).

In 2012, number of leaves plant ${ }^{-1}$ was higher than in 2013 while soybean sown in late July gave more leaves plant $^{-1}$, closely followed by late August sowing in 2012 compared to the other sowing dates assessed in the study. However, the trend was not the same in 2013. Year $\mathrm{x}$ sowing date interaction showed increase in number of leaves plant ${ }^{-1}$ when soybean was sown in early July in both years while year $\mathrm{x}$ genotype interaction depressed number of leaves plant ${ }^{-1}$ when TGx 1987-10F was sown in both years. Number of leaves plant-1 increased when TGx 1485-1D was sown in late August in 2012, while in 2013, TGx 1448-2E sown early July gave the highest number of leaves plant $^{-1}$, which invariably indicated a wider photosynthetic platform for increased grain yield. Our findings further showed that early July sowing of soybean genotypes gave the best performance in number of leaves plant ${ }^{-1}$. The highly significant variation between both years may be attributed to differences in both soil and weather environments across both years. The results are in agreement with Alghamdi (2004) in his works on yield stability of some soybean genotypes across diverse environments and ElHerty et al., (2010) in their studies on soybean genotypes under four sowing dates in middle Egypt. Similarly, works by Kandil et al., (2012) and Ngalamu et al., (2013) in drier regions of North Africa emphasized the importance of sowing date as a critical factor in soybean growth and development. Furthermore, early August sowing gave higher number of leaves plant $^{-1}$, an indication that July and August are the most appropriate times for sowing soybean in the humid agro-ecosystem of southeast Nigeria. Similarly, Bello et al., (1996) in their studies on soybean in southern guinea savanna reported that yield differences with various sowing dates can be attributed to variation in weather conditions.

Highly significant $(\mathrm{P} \leq 0.001)$ variations in number of seeds plant ${ }^{-1}$ was recorded across years, sowing dates, soybean genotypes, year $\mathrm{x}$ sowing date interactions, years $\mathrm{x}$ genotypes interactions while no significant $(\mathrm{P} \geq 0.05)$ variation was observed in sowing dates $x$ genotype interactions, as well as year $\mathrm{x}$ sowing date $\mathrm{x}$ genotype interactions (Table 02). Across years, 2012 gave the highest number of seeds plant $^{-1}$ (58) relative to 2013 (32). Soybean genotypes sown in early July gave the highest overall number of seeds plant ${ }^{-1}$ (91.74) in both cropping seasons while the reverse was the case for genotypes sown in late August (26.17). TGx $1835-10 \mathrm{E}$ gave the highest number of seeds plant $^{-1}$ in 2012 contrary to 2013 while TGx 1987-10F genotype gave the lowest number of seeds plant ${ }^{-1}$ in both years. Year $x$ sowing date interaction indicated that soybean sown early July in 2012 gave the highest seed yield plant $^{-1}$. Year $\mathrm{x}$ genotype interaction indicated significant $(\mathrm{P} \geq 0.05)$ reduction in the number of seeds plant-1 of TGx 1987-10F in both years of study while sowing date $\mathrm{x}$ genotype and year $\mathrm{x}$ sowing date $\mathrm{x}$ genotype indicated nonsignificance. 
attributes of soybean and corroborated the findings of Yari et al., (2013) in their studies on yield and yield components of some soybean cultivars in which they surmised that appropriate sowing date is one of the most effective and zero cost means of increasing crop yield, hence, good knowledge of crop response to different sowing dates within an agro-ecosystem is important in determining the most suitable sowing time for that particular crop.

In 2012, TGx 1485-1D gave the highest significant seed yield $\left(980.74 \mathrm{~kg} \mathrm{ha}^{-1}\right)$ followed by TGx $1835-10 \mathrm{E}\left(890.98 \mathrm{~kg} \mathrm{ha}^{-1}\right)$ in contrast to the results obtained in 2013, though, TGx 1987$10 \mathrm{~F}$ had the lowest $(\mathrm{P} \geq 0.05)$ seed yield in both cropping years. Year $\mathrm{x}$ sowing date interaction significantly increased seed yield when soybean was sown in early July, irrespective of the genotypes while year $\mathrm{x}$ genotype interaction $(\mathrm{P} \leq 0.01)$ indicated highest increased seed yield from TGx 1485-1D, irrespective of the sowing date. Sowing date $\mathrm{x}$ genotype interaction showed that TGx 1485-1D (207.16 kg ha-1) and TGx 1448-2E (107.53 $\left.\mathrm{kg} \mathrm{ha}^{-1}\right)$ sown in early July gave the highest seed yield, irrespective of the year, while year $\mathrm{x}$ sowing date $\mathrm{x}$ genotype interactions indicated significant $(\mathrm{P} \leq 0.01)$ higher seed yield when TGx 1485-1D genotype was sown in early July in 2012, which was higher by $87.9 \%$ compared to the lowest seed yield obtained when TGx 1448-2E was sown in late August in 2013.

The results indicated better performance of early July sowing, which can be attributed to climatic conditions such as short dry spell, high solar radiation and temperature, less cloudiness and low relative humidity, which coincides with the flowering period of the crop in the humid agro-ecological zone of south east Nigeria. The result supports the findings of Okpara and Ibiam (2000) who reported that sowing soybean between the months of July and October in the humid tropics was most suitable and favourable to the specific climatic requirements of the different phenological phases of the crop's growth and development. Furthermore, the results corroborated separate studies by Udoh (2003) and Bello et al., (1996) who submitted that sowing legumes in the Southern guinea savanna of Nigeria between mid-June and midJuly is to ensure adequate rainfall at seedling establishment, flowering and pod filling stages for maximum seed yield as well as to enhance the maturity of the legume when the weather is relatively bright and sunny as soybean seed quality and viability are greatly impaired if the crop matures during the rains.

Table 03: Seed yield $\left(\mathrm{kg} \mathrm{ha}^{-1}\right)$ of four soybean genotypes as influenced by genotype by sowing date interaction in 2012 and 2013 cropping seasons

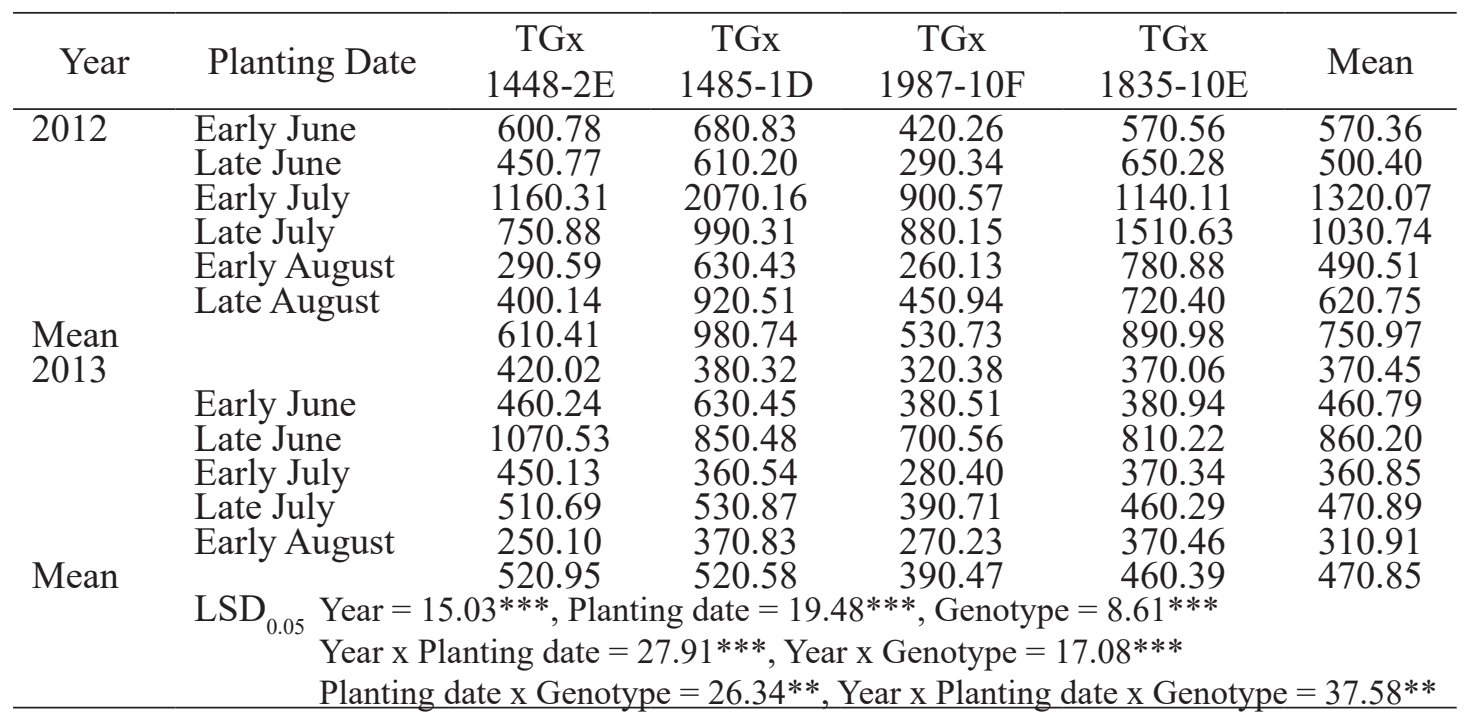


Year $\mathrm{x}$ sowing date interaction significantly increased soybean seed yield when sown early July, irrespective of the genotypes while year $x$ genotype interaction increased seed yield of TGx 1485-1D, irrespective of the sowing date. Sowing date $\mathrm{x}$ genotype interaction increased seed yield of TGx 1485-1D (207.16 $\left.\mathrm{kg} \mathrm{ha}^{-1}\right)$ and TGx 1448-2E (107.53 $\left.\mathrm{kg} \mathrm{ha}^{-1}\right)$, irrespective of the year, while year $\mathrm{x}$ sowing date $\mathrm{x}$ genotype interactions indicated significant $(\mathrm{P} \leq 0.01)$ higher seed yield when TGx 1485-1D genotype was sown in early July in 2012, which was higher by $87.9 \%$ compared to the lowest seed yield obtained when TGx 1448-2E was sown in late August in 2013.

Correlation studies (Table 04) indicated that except number of days to flowering and pod filling time, which indicated positive but nonsignificant $(\mathrm{P} \geq 0.05)$ relationship with seed yield of soybean, the other growth and yield characters (establishment count, plant height, number of leaves plant ${ }^{-1}$, number of branches plant $^{-1}$, root length, number of nodules plant ${ }^{-1}$, nodule dry weight plant $^{-1}$, number of days to physiological maturity, number of pods plant ${ }^{-1}$, number of seeds plant ${ }^{-1}$ and 100-seed weight) indicated positive and significant $(\mathrm{P} \leq 0.01)$ relationship with seed yield of cowpea. Plant height had positive and significant correlation $(\mathrm{P} \leq 0.01)$ with number of leaves plant $^{-1}$, number of branches plant ${ }^{-1}$, number of seeds plant $^{-1}$, number of pods plant ${ }^{-1}$ and number of nodules plant ${ }^{-1}$. Also, number of pods plant ${ }^{-1}$ was significantly and positively correlated with number of leaves plant ${ }^{-1}\left(\mathrm{r}=0.508^{* *}\right)$, root length $\left(\mathrm{r}=0.440^{* *}\right)$, number of nodules plant $^{-1}(r=0.407 * *)$, number of branches plant $^{-1}\left(\mathrm{r}=0.310^{* *}\right)$ and nodule dry weight/ plant $\left(\mathrm{r}=216^{* *}\right)$ while 100 seed weight was positively and significantly correlated with days to flowering $\left(\mathrm{r}=0271^{* *}\right)$ and pod filling time was highly and positively correlated with days to physiological maturity $\left(\mathrm{r}=0.895^{* *}\right)$. Similar results were obtained by Ghodrati (2013) in Iran and Ojo et al., (2007) in Nigeria in their various studies on soybean characters. Furthermore, Cumudini et al., (2001), Ojo and Amanze (2001) and Rajanna et al., (2000) who in their separate investigations observed significant and positive correlations between seed yield and number of seeds plant ${ }^{-1}$, seed yield and 1000-seed weight as well as number of pods plant ${ }^{-1}$ and number of branches plant ${ }^{-1}$ in tropical soybean crop. The strong correlation of these traits with seed yield suggested that they could be used as selection indices for yield improvement of soybeans under the prevailing agro-ecology.

Table 04: Linear correlation matrix between different agronomic characters and seed yield of four soybean genotypes

\begin{tabular}{|c|c|c|c|c|c|c|c|c|c|c|c|c|c|}
\hline & 2 & 3 & 4 & 5 & 6 & 7 & 8 & 9 & 10 & 11 & 12 & 13 & $\begin{array}{l}\text { YLD } \\
\mathrm{Kg} \\
\mathrm{ha}^{-1}\end{array}$ \\
\hline 1 & $0.64^{*+}$ & $0.51^{* *}$ & $0.39^{* *}$ & $0.23^{* *}$ & $0.30^{* *}$ & $0.24^{* *}$ & $-0.21^{\text {ns }}$ & $-0.02^{\text {ns }}$ & $-0.11^{\text {ns }}$ & $0.38^{* *}$ & $0.45^{* *}$ & $-0.02^{\text {ns }}$ & $0.52^{* *}$ \\
\hline 2 & - & $0.83^{* *}$ & $0.50^{* *}$ & $0.33^{* *}$ & $0.38^{* *}$ & $0.20^{* *}$ & $-0.21^{\mathrm{ns}}$ & $-0.06^{\mathrm{ns}}$ & $-0.14^{\mathrm{ns}}$ & $0.44^{* *}$ & $0.48^{* *}$ & $-0.03^{\mathrm{ns}}$ & $0.46^{* *}$ \\
\hline 3 & & - & $0.62 *$ & $0.32^{* *}$ & $0.34^{* *}$ & $0.24^{* *}$ & $-0.20^{\mathrm{ns}}$ & $-0.06^{\text {ns }}$ & $-0.14^{\mathrm{ns}}$ & $0.51^{* *}$ & $0.51^{* *}$ & $-0.01^{n s}$ & $0.58^{* *}$ \\
\hline 4 & & & - & $0.18^{*}$ & $0.18^{*}$ & $0.13^{\text {ns }}$ & $-0.21^{\mathrm{ns}}$ & $0.07^{\mathrm{ns}}$ & $-0.01^{\mathrm{ns}}$ & $0.31^{* *}$ & $0.32^{* *}$ & $-0.03^{\mathrm{ns}}$ & $0.38^{* *}$ \\
\hline 5 & & & & - & $0.37^{* *}$ & $0.38^{* *}$ & $0.08^{\text {ns }}$ & $0.05^{\mathrm{ns}}$ & $0.10^{\mathrm{ns}}$ & $0.44^{* *}$ & $0.38^{* *}$ & $0.66^{\text {ns }}$ & $0.39^{* *}$ \\
\hline 6 & & & & & - & $0.62^{* *}$ & $-0.05^{\mathrm{ns}}$ & $0.02^{\text {ns }}$ & $-0.00^{\mathrm{ns}}$ & $0.41^{* *}$ & $0.36^{* *}$ & $-0.05^{\mathrm{ns}}$ & $0.40^{* *}$ \\
\hline 7 & & & & & & - & $-0.07^{\mathrm{ns}}$ & $0.03^{\text {ns }}$ & $-0.01^{\mathrm{ns}}$ & $0.22^{* *}$ & $0.23^{* *}$ & $0.04^{\text {ns }}$ & $0.40^{* *}$ \\
\hline 8 & & & & & & & - & $-0.36^{\text {ns }}$ & $0.08^{n s}$ & $0.12^{\mathrm{ns}}$ & $-0.01^{\mathrm{ns}}$ & $0.27^{* *}$ & $0.02^{\mathrm{ns}}$ \\
\hline 9 & & & & & & & & - & $0.90^{* *}$ & $-0.02^{\text {ns }}$ & $0.06^{\mathrm{ns}}$ & $-0.04^{\text {ns }}$ & $0.04^{\mathrm{ns}}$ \\
\hline 10 & & & & & & & & & - & $0.04^{\mathrm{ns}}$ & $0.06^{\text {ns }}$ & $0.08^{\text {ns }}$ & $0.06^{\text {ns }}$ \\
\hline 11 & & & & & & & & & & - & $0.81^{* *}$ & $-0.08^{\mathrm{ns}}$ & $0.72^{* *}$ \\
\hline 12 & & & & & & & & & & & - & $-0.14^{\mathrm{ns}}$ & $0.65^{* *}$ \\
\hline 13 & & & & & & & & & & & & - & $0.169^{*}$ \\
\hline
\end{tabular}

1, Establishment count; 2, Plant height (cm); 3, number of leaves plant ${ }^{-1} ; 4$, number of branches plant ${ }^{-1} ; 5$, root length (cm); 6 , number of nodules plant $^{-1} ; 7$, nodules dry weight plant ${ }^{-1}(\mathrm{~g}) ; 8$, number of days to flowering; 9 , pod filling time; 10, number of days to physiological maturity; 11, number of pods plant ${ }^{-1} ; 12$, number of seeds plant ${ }^{-1} ; 13,100$-seed weight $(\mathrm{g})$; YLD, seed yield $\left(\mathrm{kg} \mathrm{ha}^{-1}\right) .{ }^{*}$, and ${ }^{* *}$, Correlation is significant at 0.05 and 0.011 evel of probability, respectively; ns, non significant. 
Highly significant $(\mathrm{P} \leq 0.01)$ and positive association was observed between days to maturity and pod-filling time $\left(\mathrm{r}=0.895^{* *}\right)$, plant height and number of leaves plant ${ }^{-1}(r=$ $\left.0.829^{* *}\right)$ and between number of pods plant ${ }^{-1}$ and number of seeds plant ${ }^{-1}\left(\mathrm{r}=0.812^{* *}\right)$. These results are consistent with the findings of Showkat and Tyagi (2010) as well as Malik et al., (2007) who reported positive and significant correlation between seed yield and number of pods plant ${ }^{-1}$ as well as seed yield and 100 -seed weight. Furthermore, studies by Abd El-Mohsen et al., (2013), Kobraee and Shamsi (2011) as well as Adeniji (2007) revealed that seed yield is a function of integrated effects of various yield components such as number of pods plant ${ }^{-1}$, number of leaves plant ${ }^{-1}$, number of seeds plant $^{-1}$ and 100-seed weight developed under a particular set of environmental conditions.

Path coefficients analysis (Table 05), which identified the correlation coefficients of the yield components with seed yield to show the direct and indirect effects of each component aimed at knowing the contribution of each character to the yield indicated that number of pods plant ${ }^{-1}$ had the highest positive direct effect (0.49) and exhibited strong positive influence on seed yield with correlation coefficients of
0.724 while number of seeds plant ${ }^{-1}$ had weak positive direct effect on seed yield (0.14) but showed high positive indirect effect via number of pods plant $^{-1}(0.40)$. Similar results were reported by Machikowa and Laosuwan (2011) as well as Malik et al., (2007) in their works on the yield and yield components of some early maturing soybean. Positive direct effects were also recorded for number of leaves plant ${ }^{-1}$ (0.27), nodule dry weight (0.23) and 100-seed weight $(0.22)$ while plant height, root length and number of nodules plant ${ }^{-1}$ exhibited weak and negative direct effects on seed yield.

The results are in consonance with the findings of Li et al., (2013), Ashard et al., (2006), Sudaric and Vrataric (2002), Rajanna et al., (2000) in their various studies on soybean in different ecological areas. Furthermore, positive and high total effects of these characters to seed yield revealed their importance in determining seed yield in soybean, an indication that their improvement can positively enhance yield of the legume. The residual factor $(\mathrm{R})$, which indicated how effective the casual factor accounted for the variability of cowpea seed yield, was 0.32 . This implied that the plant characters explained $68 \%$ of the variability in seed yields in the four cowpea genotypes.

Table 05: Path coefficients analysis showing direct and indirect effects of ten growth and yield characters on seed yield of soybean $\left(\mathrm{kg} \mathrm{ha}^{-1}\right)$

\begin{tabular}{ccccccccccc}
\hline & PH & NL & NB & RL & NN & NDW & NP & NS & 100-SWT & YLD \\
\hline PH & $\mathbf{- 0 . 1 1}$ & 0.23 & 0.03 & -0.01 & -0.01 & 0.05 & 0.22 & 0.07 & -0.01 & 0.46 \\
NL & -0.09 & $\mathbf{0 . 2 7}$ & 0.03 & -0.01 & -0.01 & 0.05 & 0.25 & 0.07 & -0.00 & 0.58 \\
NB & -0.05 & 0.17 & $\mathbf{0 . 0 5}$ & -0.01 & -0.01 & 0.03 & 0.15 & 0.05 & -0.01 & 0.38 \\
RL & -0.04 & 0.09 & 0.01 & $\mathbf{- 0 . 0 3}$ & -0.01 & 0.09 & 0.22 & 0.05 & 0.015 & 0.39 \\
NN & -0.04 & 0.09 & 0.01 & -0.01 & $\mathbf{- 0 . 0 3}$ & 0.14 & 0.20 & 0.05 & -0.01 & 0.40 \\
NDW & -0.02 & 0.06 & 0.01 & -0.01 & -0.02 & $\mathbf{0 . 2 3}$ & 0.11 & 0.03 & 0.008 & 0.40 \\
NP & -0.05 & 0.14 & 0.02 & -0.01 & -0.01 & 0.05 & $\mathbf{0 . 4 9}$ & 0.12 & -0.02 & 0.72 \\
NS & -0.05 & 0.14 & 0.02 & -0.01 & -0.01 & 0.05 & 0.40 & $\mathbf{0 . 1 4}$ & -0.03 & 0.65 \\
100-SWT & 0.00 & -0.00 & -0.00 & -0.00 & 0.00 & 0.01 & -0.04 & -0.02 & $\mathbf{0 . 2 2}$ & 0.17 \\
R & & & & & & & & & & 0.32 \\
\hline
\end{tabular}

PH, Plant height (cm); NL, number of leaves plant ${ }^{-1}$; NB, number of branches plant ${ }^{-1}$; RL, root length (cm); NN, number of nodules plant ${ }^{-1}$; NDW, nodules dry weight plant ${ }^{-1}(\mathrm{~g})$; NP, number of pods plant ${ }^{-1}$; NS, number of seeds plant $^{-1}$; 100-SWT, 100-seed weight (g); YLD, seed yield ( $\left.\mathrm{kg} \mathrm{ha}^{-1}\right)$; R, Residual effect of cowpea genotype. 
Genotype and Genotype $\mathrm{x}$ Environment interaction (GGE) bi-plot model was used to evaluate the stability of the soybean genotypes across the two environments (years) as shown in Figures 1ab, 2ab, 3ab and 4ab. The model is an efficient tool employed in identifying and selecting the most stable, high performing crop genotypes that are best suitable under a given set of environmental conditions. According to Nwofia (2012) the evaluation of cultivars in contrasting environments and across years is an essential step in determining their desirability and average response across the environments that have a wide scope of adaptation. The biplot analyses (Figures 01a, 02a, 03a and 04a) indicated that a genotype identified further away from the bi-plot origin on either side of the stability line represents relatively lower

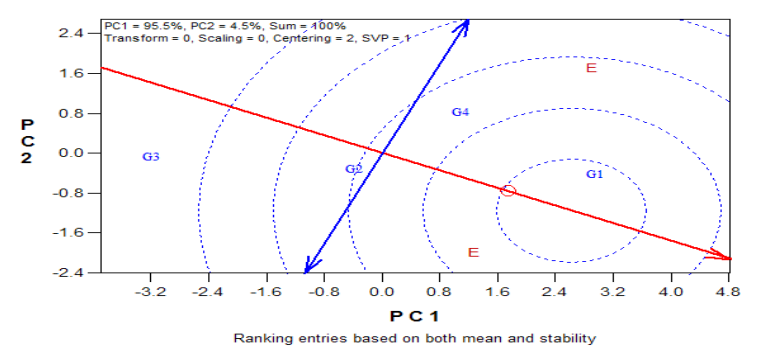

G1=TGx1448-2E, G2=TGx1485-1D, G3=TGx198710F, G4=TGx1835-10E (E1=2012, E2=2013).

Figure 01a: GGE bi-plot based on genotypefocused scaling for comparison of the genotypes with ideal genotype for days to physiological maturity.

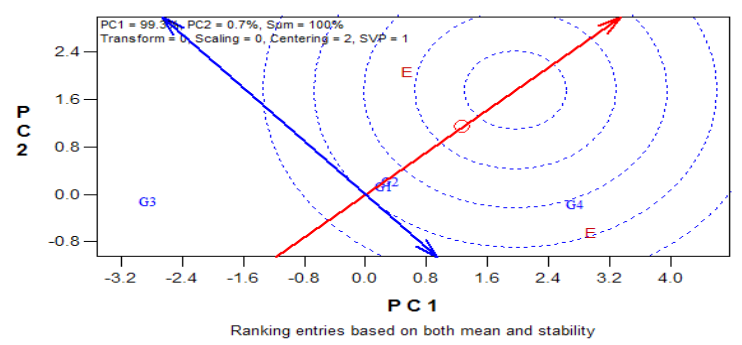

G1=TGx1448-2E, G2=TGx1485-1D, G3=TGx198710F, G4=TGx1835-10E (E1=2012, E2=2013).

Figure 02a: GGE bi-plot based on genotypefocused scaling for comparison of the genotypes with ideal genotype for number of pods plant-1. stability while Figures 01b, 02b, 03b and 04b expressed the mean performance versus the stability of the soybean genotypes across the two environments (years). TGx 1448-2E soybean genotype showed highest number of days to physiological maturity by being closest to the ideal genotype (Figure 01a) while mean versus stability analysis (Figure $01 \mathrm{~b}$ ) showed TGx 1485-1D as the most stable genotype by being closest to the average tester coordinate (ATC) horizontal axis. Among the soybean genotypes studied, TGx 1835-10E had the highest number of pods plant ${ }^{-1}$ and was closest to the ideal genotype (Figures 02a and 02b). However, it indicated less stability relative to TGx 1485-1D and TGx 1448-2E, which had above average pod number and high stability for the plant character.

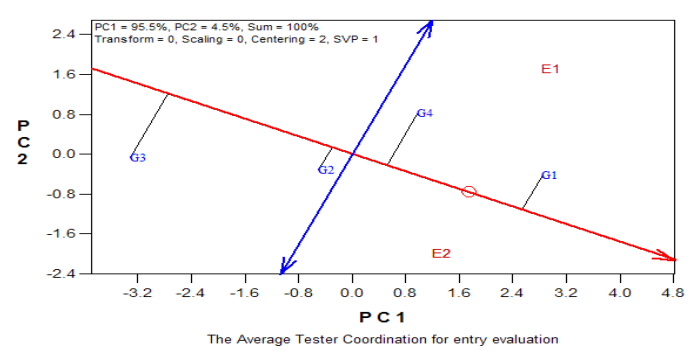

G1=TGx1448-2E, G2=TGx1485-1D, G3=TGx198710F, G4=TGx1835-10E (E1=2012, E2=2013).

Figure 01b: GGE bi-plot of means vs. stability of four soybean genotypes for days to maturity.

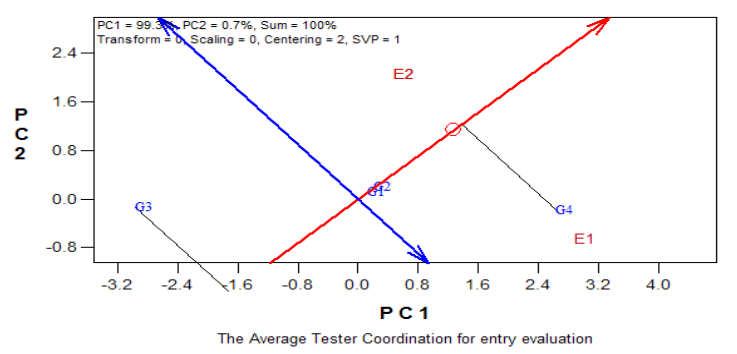

G1=TGx1448-2E, G2=TGx1485-1D, G3=TGx198710F, G4=TGx1835-10E (E1=2012, E2=2013).

Figure 02b: GGE bi-plot of means vs. stability of four soybean genotypes for number of pods plant-1. 


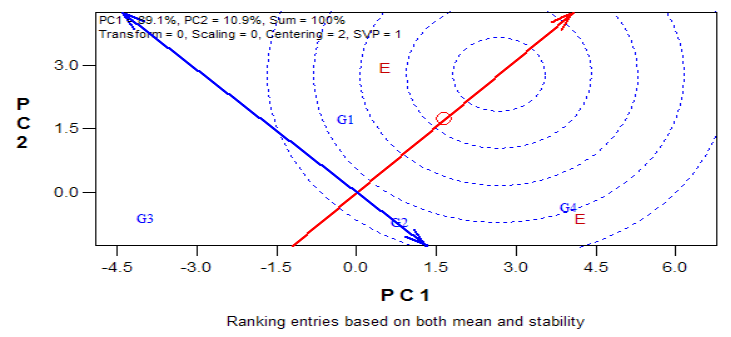

G1=TGx1448-2E, G2=TGx1485-1D, G3=TGx198710F, G4=TGx1835-10E, E1=2012, E2=2013)

Figure 03a: GGE-bi-plot based on genotypefocused scaling for comparison of the genotypes with ideal genotype for number of seeds/plant

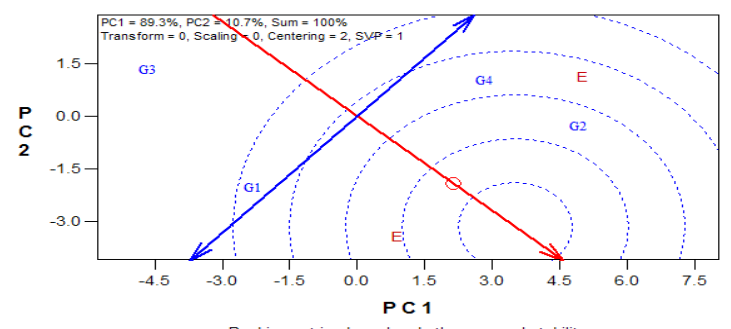

$\mathrm{G} 1=\mathrm{TGx} 1448-2 \mathrm{E}, \mathrm{G} 2=\mathrm{TGx} 1485-1 \mathrm{D}$, $\mathrm{G} 3=\mathrm{TGx} 1987-10 \mathrm{~F}, \mathrm{G} 4=\mathrm{TGx} 1835-10 \mathrm{E}$ $(\mathrm{E} 1=2012, \mathrm{E} 2=2013)$.

Figure 04a: GGE-bi-plot based on genotypefocused scaling for comparison of the genotypes with ideal genotype for seed yield (kg ha-1).

The soybean genotype TGx 1835-10E had the highest number of seeds plant ${ }^{-1}$ but was furthest from the ATC horizontal axis indicating high instability for the character (Figure 03a and 03b) while TGx 1485-1D indicated high stability compared to the other genotypes. Ranking the genotypes for seed yield, TGx 1485-1D showed superiority compared to the other genotypes and was closest to the ideal genotype. TGx 1987$1 \mathrm{~F}$ was the most stable but lowest yielding genotype in the two cropping seasons (Figures $04 \mathrm{a}$ and $04 \mathrm{~b}$ ). The results are in consonance with investigations by Jandong et al., (2011), Kaya et al., (2006), Crossa et al., (2002) and Yan (2002) in their various studies in which they reported that combined effects of genotype, environment and genotype $\mathrm{x}$ environment $(\mathrm{GxE})$ interactions

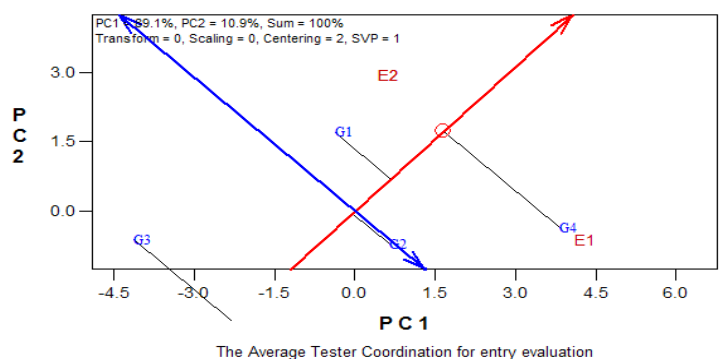

$\mathrm{G} 1=\mathrm{TGx} 1448-2 \mathrm{E}, \mathrm{G} 2=\mathrm{TGx} 1485-1 \mathrm{D}, \mathrm{G} 3=\mathrm{TGx} 1987-$

10F, G4=TGx1835-10E, E1=2012, E2=2013)

Figure 03b: GGE bi-plot of means vs. stability of four soybean genotypes for number of seeds/plant

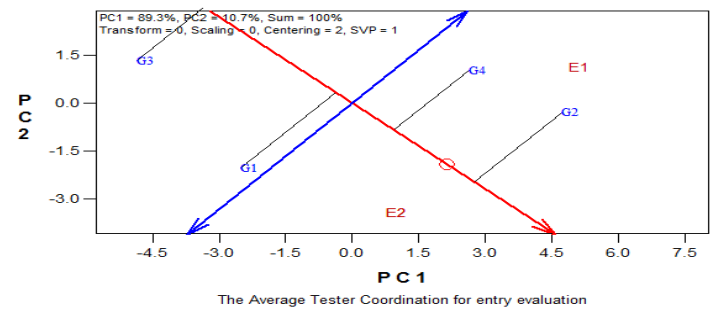

$\mathrm{G} 1=\mathrm{TGx} 1448-2 \mathrm{E}, \mathrm{G} 2=\mathrm{TGx} 1485-1 \mathrm{D}, \mathrm{G} 3=\mathrm{TGx} 1987-$ 10F, G4=TGx1835-10E (E1=2012, E2=2013).

Figure 04b: GGE bi-plot of means vs. stability of four soybean genotypes for seed yield (kg ha-1.

determine the yield of a crop. Furthermore, large yield variations due to environment is important in genotype evaluation and mega-environment investigation, suggesting the use of GGE bi-plots as the appropriate tool for analyzing multiple environment trials data. Similarly, Crossa et $a l$. , (2002) suggested that genotype main effects and genotype $\mathrm{x}$ environment interaction (GEI) effects are two outstanding sources of variation that are relevant for genotype evaluation and should be considered simultaneously and appropriately.

TGx1448-2E and TGx1485-1D showed little genotype-by-environment interaction for number of pods plant ${ }^{-1}$, indicating high stability for the character. However, our findings did not 
identify any ideal soybean genotype among the ones evaluated in the agro-ecological zone. According to Akande et al., (2009), Yan and Hunt (2001) as well as Yan et al., (2000) an ideal genotype is one that gives the highest yield across all test environments with greater vector length and zero genotype by environment interaction. Results obtained revealed that the performance of TGx1485-1D was above average for most of the characters tested, hence showed superiority in seed yield production and can be subjected to further investigations.

\section{CONCLUSION}

Sowing date strongly influenced yield and yield components of soybean. July appeared to be the most appropriate sowing time for soybean in the region. Significant year $\mathrm{x}$ sowing date $\mathrm{x}$ genotype interactions observed for most of the characters indicated that the genotypes responded differently to varying sowing dates across both years under the agro-ecological zone. Among the four genotypes, TGx14851D significantly and consistently had the best performance in seed yield and most of the characters studied across the two years, followed by TGx1835-10E, an indication of better adaptability to the soil and climatic conditions of the environment. These genotypes therefore can be suggested as good breeding materials that can be used in developing soybean varieties with high adaptation to the agro-ecology.

Correlation analysis and path coefficients analysis showed that number of pods plant ${ }^{-1}$ among other traits is the most important contributor to soybean seed yield, hence should be considered as an important selection index for soybean improvement aimed at developing high yielding varieties in the region. However, other important determinants of soybean seed yield, which serve as good selection indices for yield improvement, include number of leaves plant $^{-1}$, number of seeds plant ${ }^{-1}$ and 100 seed weight. The soybean genotypes exhibited different levels of stability for the different characters tested with TGx1485-1D indicating values that were above average for most of the characters evaluated, hence was superior in seed yield. Though the genotype (TGx1485-1D) exhibited low yield stability across the two years, in the GGE bi-plot ranking, it ranked closest to the ideal genotype. Therefore, it is suitable for cultivation in the humid agro-ecological zone of southeast Nigeria and could be exploited for future breeding programs aimed at developing high yielding, adaptable and stable genotypes for the region.

\section{REFERENCES}

Abd El-Mohsen, A. A., G. O. Mahmoud and S. A. Safina (2013). Agronomical evaluation of six soybean cultivars using correlation and regression analysis under different irrigation regime conditions. Journal of Plant Breeding and Crop Science (5)5: pp 91-102. http://dx.doi. org/10.5897/JPBCS2013.0389

Adeniji, O. T. (2007). Stepwise regression and path analysis of dry matter accumulation in the vegetative and reproduction parts of soybeans [Glycine max (L.) Merr]. Agriculture Journal 2(6): pp 697-701.

Aduloju, M. O., J. Mahamood and Y. A. Abayomi (2009). Evaluation of soybean [Glycine Max (L.) Merrill] genotypes for adaptability to a southern Guinea savanna environment with and without P fertilizer application in North central Nigeria. African Journal of Agricultural Research 4 (6): pp 556-563. 
Akande, S. R., O. F. Owolade and J. A. Ayanwole (2007). Field evaluation of soybean varieties at Ilorin in the southern guinea savanna ecology of Nigeria. African Journal of Agricultural Research . 2(8): pp 356-359.

Alghamdi, S. S. (2004). Yield stability of some soybean genotypes across diverse environments. Pakistan Journal of Biological Sciences 7 (12): pp 2109-2114. http://dx.doi.org/10.3923/ pjbs.2004.2109.2114

Arshad, M., N. Ali and A. Ghafoor (2006). Character correlationand path coefficient in soybean [Glycine max (L.) Merrill]. Pakistan Journal of Botany 38: pp 121-130.

Azadbakht, L., R. Shakerhosseini, S. Atabak, M. Jamshidian, Y. Mehrabi and A. Esmaill- Zadeh (2003). Beneficiary effects of dietary soy protein on lowering plasma levels of lipid and improving kidney function in type II diabetes with nephropathy. European Journal of Clinical Nutrition 57: pp 1292-1294. http://dx.doi.org/10.1038/sj.ejcn.1601688

Azari, A. and M. R. Khajepour (2003). Effect of planting pattern on growth, development, grain yield and yield components in sunflower cv. Kooseh Isfahan in spring planting. Journal of Science and Technology of Agriculture and Natural Resources 7: pp 155-167.

Bello, L. L., A. A. Ojo, M. O. Adeyemo, Y. M. Omojor (1996). Effect of planting date on y i e 1 d component and seed viability in soybean in southern Guinea Savanna, Nigeria. African Crop Science Journal 4: pp 393-397.

Crossa, J., B. Cornelius and W. Yan (2002). Biplots of linear-bilinear models for studying crossover genotype X environment interaction. Crop Science 42: pp 136-144. http://dx.doi. org/10.2135/cropsci2002.0619

Cumudini, S., D. J. Hume, and G. Chu (2001). Genetic improvement in short season soybean: Dry matter accumulation, partitioning, and leaf area duration. Crop Science 41:391-398. http:// dx.doi.org/10.2135/cropsci2001.412391x

Dewey, D. R and K. H. Lu (1959). A correlation and path coefficient analysis of components of crested wheat grass seed production. Agronomy Journal 5: pp 515-618. http://dx.doi. org/10.2134/agronj1959.00021962005100090002x

El-Herty, E. H., A. M. A. Rizk, E. K. Gendy and H. T. Abd El-Aal (2010). Performance of soybean genotypes under four sowing dates at middle Egypt. Egyptian Journal of Plant Breeding 14: pp 283-293.

Fehr, W. R. and C. F. Caviness (1977). Stages of soybean development. Cooperative Extension Service, Agriculture and Home Economics Experiment Station, Iowa State University, Ames, Iowa.

Gabriel, K. R. (1971). The Biplot Graphic of Matrices with Application to Principal Component Analysis. Biometrics, 58: pp 453-467. http://dx.doi.org/10.1093/biomet/58.3.453

Ghodrati, G. H. (2013). Study of genetic variation and broad sense heritability for some qualitative and quantitative traits in soybean (Glycine max L.) genotypes. Current Opinion in Agriculture 1: pp 31-35. 
Jandong, E. A., M. I. Uguru, and B. Oyiga (2011). Determination of yield stability of soybean genotypes across diverse soil pH levels using GGE biplot analysis. Journal of Applied Biosciences 24: pp 2924- 2941.

Kandil, A. A., A. E. Sharief1, A. R. Morsy and A. I. Manar El-Sayed (2012). Performance of some promising genotypes of soybean under different planting dates using biplots analysis. Journal of Basic and Applied Science 8: pp 379-385.

Kaya, Y. M., M. Akcura and S. Taner (2006). GGE-biplot analysis of multi-environment yield trials in bread wheat. Turkish Journal of Agriculture and Forestry 30: pp 325-337.

Kobraee, S. and K. Shamsi (2011). Effect of irrigation regimes on quantitative traits of soybean (Glycine Max L.). Asian Journal of Experimental Biological Sciences 2 (3): pp 441-448.

Machikowa, T. and P. Laosuwan (2011). Path coefficient analysis for yield of early maturing soybean. Songklanakarin Journal of Science and Technology 33 (4): pp 365-368.

Malik, M. F. A., M. Ashraf, A. S. Qureshi and A. Ghafoor (2007). Assessment of genetic variability, correlation and path analyses for yield and its components in soybean Pakistan Journal of Botany 42(2): pp 971-976

Murray-Kolb, L. E., R. Welch, E. C. Theil, and J. L. Beard (2003). Women with low iron stores absorb iron from soybeans. The American Journal of Clinical Nutrition 77: pp 180-184.

Ngalamu, T., M. Ashraf and S. Meseka (2013). Soybean (Glycine max L) genotype and environment interaction effect on yield and other related traits. American Journal of Experimental Agriculture 3 (4): pp 977-987. http://dx.doi.org/10.9734/AJEA/2013/5069

Nwofia, G.E. (2012). Yield and yield component in vegetable cowpea on an ultisol. African Journal of Agricultural Research 7 (28): pp 4097-4103. http://dx.doi.org/10.5897/AJAR12.402

Ojo, D. K and C. O. Amanze (2001). Prediction of grain yield through heritability and genetic advance of yield parameters in soybeans. Journal of Ecology 3: pp 10-13.

Ojo, D. K., J. O. Amira and O. A. Oduwaye (2007). Genetic variability for biological nitrogen fixation traits in tropical soybeans [Glycine max (L) Merr]. Nat. and Sci. 5(2).

Okpara, D. A. and B. Ibiam (2000). Evaluation of soybean varieties for adaptability to a humid tropical environment in South-eastern Nigeria. Journal of Sustainable Agriculture and the Environment 2: pp 26-31.

Rajanna, M. V., B. Pramilarani and A. Satyanarayana (2000). Genetic variability, correlation and path analysis in soybean. Journal of Oilseeds Research 17 (1): pp 32-35.

Rao, M. S. S., B. G. Mullinix, M. Rangappa, E. Cebert, A. S. Bhagsari, V. T. Sapra, J. M. Joshi and R. B. Dadson (2002). Genotype x Environmental Interactions and yield stability of food grade soybean genotypes. Agronomy Journal 94: pp 72-80. http://dx.doi.org/10.2134/ agronj2002.0072

SAS Institute (1997). SAS/STAT Users' Guide. Version 6, Fourth Edition. Cary, NC, USA. 
SPSS Statistical Package for Windows (2010) SPSS for windows. Release 17.0 Standard Version.

Showkat, M. and S. D. Tyagi (2010). Correlation and path coefficient analysis of some traits in soybean (Glycine max L. Merrill.). Research Journal of Agricultural Science 1(2): pp 102106.

Sudaric, A. and M. Vrataric (2002). Variability and interrelationships of grain quantity and quality characteristics in soybean. Die Bodenkultur 53: pp 137-142.

Sudarić , A., M. Vratarić and I. Rajcan (2006). Evaluation of agronomic performance of domestic and exotic soybean germplasm in Croatia. Izvorni Znanstveni Ćlanak, pp 1-7.

Yan, W. (2002). Singular-value partitioning in biplot analysis of multienvironment trial data. Agronomy Journal 94: pp 990-996. http://dx.doi.org/10.2134/agronj2002.0990

Yan, W. and L. A. Hunt (2001). Genetic and environmental causes of genotype by environment interaction for winter wheat yield in Ontario. Crop Science 41: pp 19-25. http://dx.doi. org/10.2135/cropsci2001.41119x

Yan, W., L. A. Hunt, Q. Sheng and Z. Szlavnics (2000). Cultivar evaluation and megaenvironment investigation based on the GGE biplot. Crop Science 40: pp 597-605. http://dx.doi. org/10.2135/cropsci2000.403597x

Yari, V., A. Frnia, A. Maleki, M. Moradi, R. Naseri, M. Ghasemi and A. Lotfi (2013). Yield and yield components of soybean cultivars as affected by planting date. Bulletin of Environment, Pharmacology and Life Sciences 2 (7): pp 85- 90 